\title{
A Path Model "Why-What-How-When" to Implement an IC Reporting
}

\author{
Paola Demartini ${ }^{1} \&$ Paola Paoloni ${ }^{2}$ \\ ${ }^{1}$ Department of Business Studies, Roma TRE University, Rome, Italy \\ ${ }^{2}$ Department of Business Studies, Niccolò Cusano University, Rome, Italy \\ Correspondence: Paola Paoloni, Full Professor of Economia Aziendale, Department of Business Studies, Niccolò \\ Cusano University, Rome, Italy. E-mail: paola.paoloni11@gmail.com
}

Received: February 5, 2017

doi:10.5539/ijbm.v12n6p11

\begin{abstract} "why-what-how-when" agenda, which will be applied in the case study:

1. Why implement IC reporting in a specific context?

2. What IC approach/tool is suitable to satisfy users' informational needs?

3. How is the quality of information?

4. When is information available?
\end{abstract}

The purpose of this paper is to present the results of an empirical study and the critical success factors for implementing Intellectual Capital (IC) reporting. Selecting an IC model to be implemented in a specific context at a particular time depends on several contingent factors. In light of this, we propose the following

The research is qualitative and focused on a case study in order to understand the dynamics of a given process. The company analyzed designs and develops Large Systems for Homeland Protection.

The analyzed case study shows that there isn't "one best way" to report on intangibles. Thus, the main critical factors of the process investigated are the following: accurate identification of actors involved in the decision-making process; quality and availability of information.

The case study allows us to analyze how changes in decision maker(s), users' informational needs and information quality can impact the selection of the framework and its relative artifact/tool to be used to report on intangibles.

Keywords: intellectual capital, reporting, case study

\section{Introduction}

The purpose of this paper is to present the results of an empirical study and the critical success factors for implementing the development of an Intellectual Capital (IC) model.

While a huge variety of theoretical models for managing IC have been generated in the last decades, understanding how IC management models operate still continues to be a challenging issue. Our paper is positioned in the so-called "third stage of research on IC" (Guthrie et al., 2012; Dumay, 2013; Dumay and Garanina, 2013). In this stage, the research focus is on the usefulness of IC information in decision-making from a contingency perspective (Becerra-Fernandez, 2001), and the main purpose is not to identify a "one-size-fits-all" measurement of corporate intangible assets (Kujansivu, 2009; Lönnqvist et al., 2009; Chiucchi, 2013a, b; Demartini and Paoloni 2013a, b; Giuliani, 2013).

Adopting a pragmatic lens of analysis, we suggest that in order to select a suitable IC approach among the many already existing, it is important to wonder why, what, how and when an approach needs to be implemented. The main principle for our research is taking into consideration the distinct informational needs of a company's stakeholders. The stakeholders are the individuals or groups who depend on the company for the realization of personal goals and on whom the company is dependent. Therefore, investors, lenders, suppliers, customers, managers and employees, as well as many other groups can all be regarded as stakeholders; even the community as a whole, both state and local, can be regarded as a stakeholder. To sum up, it is customary for stakeholders 
to place demands on the company and for the company to have claims on them (Freeman, 1994; 2010; Freeman et al. 2010). Their informational need is different because their demands on the company's outcomes, their objectives and their decision-making processes are different.

Subsequently, we will consider, as external stakeholders (i.e., investors, lenders, trade creditors, employees and others), users who wish to assess the stewardship or accountability of management for the resources entrusted to it in order to make their economic decisions. These decisions may include, for example, whether to hold or sell their investments in the enterprise or whether to reappoint or replace the management.

Internal stakeholders (ie, the management of an enterprise) are users who need IC informational support planning, decision-making and control responsibilities in order to manage the firm.

From a theoretical point of view, we advocate that: a) information on corporate IC should be tailored differently in light of the user's perspective (Petty et al., 2008); b) in order to choose the best suited approach, the selection process needs to individuate the tool with a theoretical framework consistent with that of the user's informational needs (Marzo, 2014).

We worked with a joint research group, analyzing a company that is a global contender and designs and develops Large Systems for Homeland Protection. As a result, it allowed us to investigate the method for selecting a functional IC approach/tool from the very beginning, and gave us the opportunity to improve the suggested path model "why-what-how-when" thanks to practical experience.

Our findings show the recognition of a decision maker/s objectives is a critical factor for the successful implementation of IC reporting, given the possibility that they could have several objectives, which can only be executed through the use of different IC approaches/tools.

Moreover, the quality of information and its cost-benefit trade-offs must be taken into consideration, in addition to the user's informational needs. Sometimes, in fact, the scarcity and/or the low-quality of information gathered may indicate the selection of alternative IC approaches used to reach objectives.

\section{Research Framework and Literature Review}

The growing importance of intangible assets in the last two decades has stimulated a wealth of studies on this topic, leading some researchers to enquire about the state of art and the future trends of this research field (Petty and Guthrie, 2000; Pew Tan et al. 2008; Guthrie et al. 2012; Edvinsson, 2013; Dumay, 2014; 2016). Within this article, we only briefly examine the main stages of IC research as identified by Guthrie et al. (2012). Initially, the scholars' efforts were focused on research identification (Roos et al., 1997), in order to define IC research boundaries and links to other disciplines (such as corporate strategy and accounting), as well as to understand its main components (OECD, 1999; Sveiby, 1997; Roos et al., 1997; Stewart, 1997; Edvinsson and Stenfelt, 1999; Edvinsson and Malone, 1997). Due to the multidimensional nature of IC, as highlighted by many members of the research community, there is not yet a common definition for IC. For the purpose of this paper, we define a company's IC as “... the sum of everything everybody in a company knows that gives it a competitive edge...Intellectual Capital is intellectual material, knowledge, experience, intellectual property, information ... that can be put to use to create value" (Dumay, 2016, p. 169).

Subsequently, in the $2^{\text {nd }}$ stage of IC research, academics and professionals focused on tools to identify, measure and report on intangible assets. The initial argument was that the growing difference between firms' market value on the stock exchange and their value in the books, revealed the existence of IC or intangible assets (Lev, 2001; Lev and Zarowin, 1999). This difference is rarely, if ever, really "filled out", because share market prices always fluctuate and it is not possible to provide a breakdown of important intangible resources (Dumay, 2012 p.7). However, it is used to extend issues of reporting beyond the financial balance sheet.

\subsection{Why and What?}

As shown in Table 1, the existing literature offers ways to justify the reporting of intangibles, both from the point of view of external and internal stakeholders. Areas relevant to internal stakeholders are: improving innovation (Sveiby et al., 2012), learning (Mouritsen, 1998; Lev\& Zambon 2003), awareness (Marr \& Chatzkel, 2004), and the adjustment of intangibles with the strategic vision of the company (Mouritsen, Larsen, \& Bukh 2001). For external stakeholders, the development of an organization's correspondence with groups of interest, their corporate image, reputation and the cut-back in the cost of capital (Andriessen, 2004; Bismuth \& Tojo, 2008) are considerably more relevant aspects (Wee \& Chua, 2016).

Naturally, there are also some costs, which are mainly associated to the act of gathering information or its disclosure (in terms of concerns about giving up proprietary information to competitors, see Graham et al., 2005, 
p. 38).

Table 1. WHY implement an IC tool?

\begin{tabular}{lll}
\hline Information Users & Main Benefits & Costs \\
\hline $\begin{array}{l}\text { External Stakeholders (i.e. investors, } \\
\text { financial analysts, rating agencies, } \\
\text { financial providers, trade partners, trade }\end{array}$ & $\begin{array}{l}\text { correspondence with groups of interest; of intuitive information to competitors } \\
\text { unions employees...) }\end{array}$ & $\begin{array}{l}\text { organization's Cost of collecting information; disclosure } \\
\text { reputant cut-back in the costs of capital }\end{array}$ \\
$\begin{array}{l}\text { Internal Stakeholders } \\
\text { (Managers) }\end{array}$ & $\begin{array}{l}\text { Development of innovation and learning; Cost of collecting information } \\
\text { adjustment of intangibles with the strategic } \\
\text { vision of the company }\end{array}$ \\
\hline
\end{tabular}

There are several approaches to identifying, measuring and managing intangibles. By the mid 2000s, "more than 50 methods were created which either helped to define IC as a whole or define different elements of IC and the list keeps growing" (Dumay \& Garanina, 2013, p. 11), while other authors claim that there are currently more than 100 methods (Pike \& Roos, 2007).

Among them are the following:

- Direct Intellectual Capital Approach: focuses on the value of specific, individual intangible assets. It includes such tools as: Citation-Weighted Patents (Bontis, 1998); The Value Explorer (Andriessen, 2004);

- Scorecard Approach: produces indicators and indices for the identification of intangible assets. It includes tools such as: Balanced Score Card (Kaplan \& Norton, 1992); Skandia Navigator (Edvinsson \& Malone, 1997); IC-Index (Roos et al., 1997); Intangible Asset Monitor (Sveiby, 1997); Value Chain Scoreboard (Lev, 2001); Intellectual Capital Statement (Danish Ministry, 2003); "Knowledge Narrative" (Mouritsen, 1998; Mouritsen \& Larsen, 2005). This approach has also been recently considered in the Integrated Reporting Framework (IIRC, 2013, p. 28) to measure the organization's effects on its different capitals (i.e., financial, manufactured, intellectual, human, social and relationship, natural).

- Market Capitalization Approach: interprets the value of a company's IC, which is the variation between the company's market capitalization and its book value. It includes tools such as: Tobin's q (Stewart 1997, Bontis 1998); Market-to-Book Value (Stewart, 1997);

- Return on Assets Approach: interprets what earning were generated from the company's invested capital. It includes measures such as: Value Added Intellectual Coefficient (VAIC) (Pulic, 1997); Knowledge Capital Earnings (Lev, 2002).

As an example, in table 2 different tools are listed considering their uses and usefulness, which is explained by their theoretical underpinning framework.

Table 2. WHAT IC tool is suitable to satisfy users' informational needs?

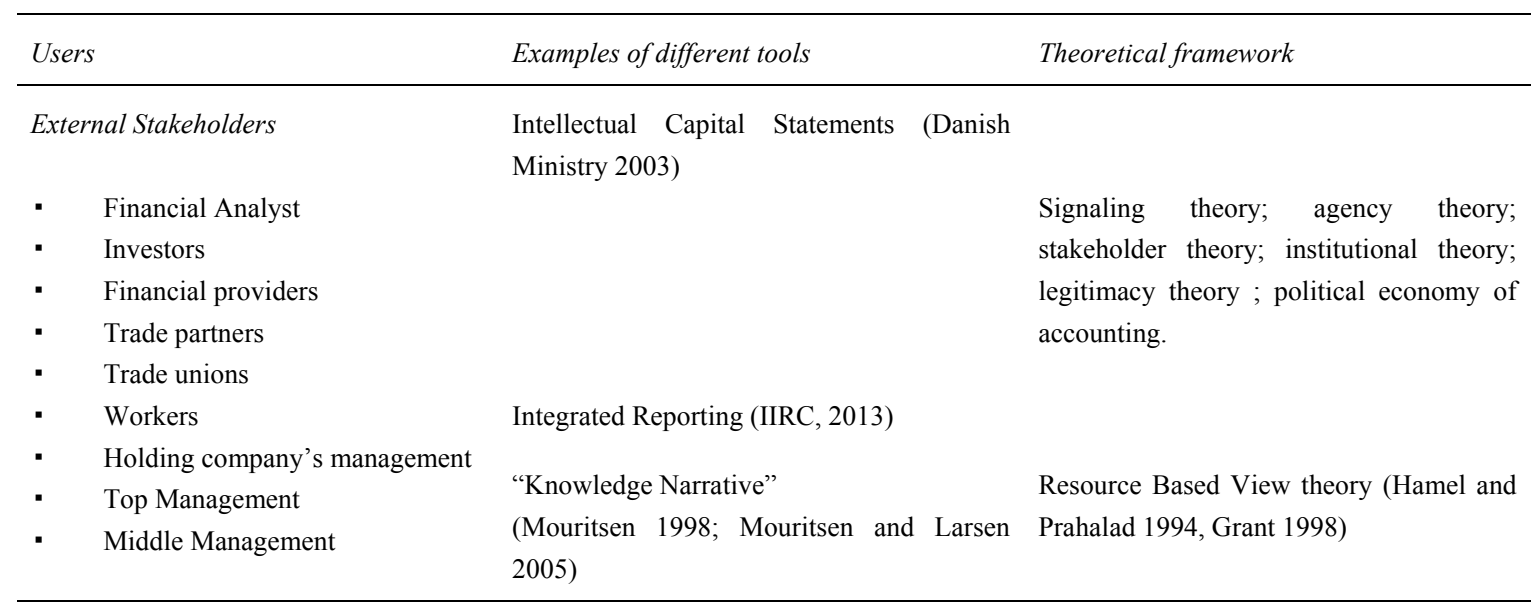


Some approaches, such as published Intellectual Capital statements, are featured in order to satisfy external stakeholders' information needs better. Others such as the Balanced scorecard (Kaplan \& Norton, 1992) fit better with managerial purposes. Finally, there are some, such as the "Knowledge Narrative" approach (Mouritsen 1998; Mouritsen \& Larsen, 2005), that can be useful for both internal and external stakeholders, while the latter needs more detailed information.

In order to choose that right approach, one should define which tool is consistent with the users informational needs in relation to its underlying theoretical framework.

Subsequently, this topic will be addressed in relation to the tools listed in table 2 .

\subsubsection{Published IC Statements}

The literature on the analysis of intangibles has allowed us to distinguish different lines of research explaining factors relevant to the disclosure of intangibles, the nature of such disclosures and the disclosure routes/formats used. Thus, the literature has mapped out a line of enquiry that results in an IC statement after a complex process (Demartini \& Paoloni, 2013b).

For some authors, IC statements explain the difference between market value and book value, showing where firms 'hide' their IC (Edvinsson \& Malone, 1997; Stewart, 1997; Sveiby, 1997; Ross et al. 1997; Lev \& Zarowin, 1998). Therefore, providing the market with appropriate information about intangible assets, among others, improves investors' decision-making; indeed, they are enabled to better assess future earnings and related risks, with reduced informational asymmetry and biases (Bismuth \& Tojo, 2008; Maditinos et al. 2011). In the same stream of research, signaling theory has been used along with agency theory to explain why listed companies with a scarce presence of institutional investors within their ownership structures (and low percentage of shares traded on the financial market) may not be incentivized to disclose IC and other voluntary information (Bozzolan et al., 2003).

However, other researchers are critical of these arguments (Dumay \& Tull, 2007; Dumay, 2012), arguing that investors are keen on more timely and relevant information than those included in voluntary annual reporting, and Dumay (2016, p. 178) affirms that "the value to investors for all forms of reports beyond regulated financial reports is questionable".

Other theories borrowed from studies on voluntary disclosure have been used to explain the reason for IC reporting, e.g., stakeholder theory (Riahi-Belkaoui, 2003; Guthrie et al., 2004), the political economy of accounting (Abeysekera \& Guthrie, 2005), legitimacy theory (Guthrie et al. 2004; Guthrie et al., 2006) and the institutional theory (Nielsen et al., 2016).

Focusing on practitioners' interest in IC statements, it is worthwhile to highlight that there was an initial ferment in the late ' $90 \mathrm{~s}$, led by the numerous projects involving researchers, professionals and public organizations, i.e., the Danish IC reporting guidelines, the InCas (Intellectual Capital Statement) project in Europe, and the Intellectual Capital Management Consultancy Program in Hong Kong. However, practitioners' engagement later declined, and other models of voluntary reporting arose as a standard to satisfy the stakeholders' informational needs (such as the Sustainability Reporting model, drawn following the Global Reporting Initiative-GRI guidelines, or the United Nations Global Compact framework in 2009). As stated by Dumay (2016, p. 168), "IC reporting started well, but soon corporate social responsibility (CSR) and sustainability reporting took over and have become the mainstays of voluntary reporting internationally".

Finally, a newfound interest of practitioners has emerged in the last years, thanks to the International Integrated Reporting Council's efforts to promote an Integrated Reporting (IR) framework; this is meant to enhance "accountability and stewardship for the broad base of capitals (financial, manufactured, intellectual, human, social and relationship, and natural)" (IIRC, 2013 p. 2). While it is too soon to judge if IR is set to become the corporate reporting norm worldwide, as envisaged by the IIRC, this framework has arguably caught the researchers' attention (Dumay et al., 2016) and has fostered an interesting debate among academics between its supporters and detractors.

\subsubsection{Balanced Scorecard VS Knowledge Narrative}

Kaplan and Norton's (1992) balanced scorecard complements the "financial" perspective with the "customer", 
"internal business process" and "learning and growth" perspectives. Mouritsen and Larsen (2005) propose a method (called "knowledge narrative") to analyze Intellectual Capital information so that it can contribute to the management of knowledge resources.

Both approaches illustrate that it is possible and very compelling to add IC to conventional financial reporting, given that they authorize the addition of "non-financial" indicators in a firm's reporting system. Therefore, we can see that there is a resemblance between balanced scorecards and Intellectual Capital statements and that both of them refer to a strategy that is positioned beyond the measurement system itself as the entity of the indicators. Moreover, they differ from the logic of double entry book-keeping for the financial accounting system and also exceed the closed system of revenues, assets, costs, profits, and liabilities.

Nevertheless, the differences are though-provoking because they are altered in terms of strategy (competitive strategy vs. competency strategy), organization (vertical vs. lateral relations), management (detailing vs. visualizing objectives) and indicators (related causally vs. bundled complementarily). For a report on the firm's budget, take a look at the available balanced scorecards, while for a report on the firm's resources, check the available Intellectual Capital statements (Mouritsen, Larsen, \& Bukh, 2001). In fact, the balanced scorecard expands on competitive strategy (Porter 1985), given that it is consistent with the industry and competitive analysis mentioned in several of Michael Porter's corporate strategy books. On the other hand, Intellectual Capital is geared towards a competency-based strategy (Hamel and Prahalad 1994, Grant 1998), generating value through employees' knowledge, skills, talents and know-how (Mouritsen, Larsen, \& Bukh, 2005).

\subsection{How and When?}

Finally, in order to answer the question's how and when to implement a selected Intellectual Capital tool, one should consider the main following factors:

- $\quad$ quality of information to be gathered (see table 3);

- cost/benefits of information. The first one is related to the costs of gathering data (in terms of time absorbed, resources dedicated and financial costs), the latter related to how the stakeholders make use of it.

Table 3. Quality of information influences: HOW to implement an IC tool

Quality of information

\begin{tabular}{cc}
\hline Relevance & Reliability \\
& Verifiability, Faithfulness, Neutrality \\
\hline
\end{tabular}

A number of studies have sought to identify criteria for assessing the quality and utility of information (FASB 2001). Relevance, Reliability and Comparability are apparently viewed as the key attributes, while other characteristics are viewed as sub-criteria contributing to the fulfillment of key properties.

Relevant information should influence economic decisions. Reliability is characterized by three qualities. The verifiability implies that it can be checked to make sure that it is correct. Faithfulness concerns the correspondence between the information and the objectives or events the numbers purport to represent. The neutrality of information implies that it is objective and free from bias. In particular, the individual or group responsibility for measuring IC is a critical factor that affects reliability. Thus, the participation of an authoritative external institute in the measurement process may have a positive effect on the reliability issue.

Furthermore, it is not sufficient that financial information is relevant and reliable at a particular time. Information about a specific organization becomes more useful if it can be used to compare information on the same enterprise for some other period and with another organization.

\subsection{A Path Model "Why-What-How-When" to Implement an IC Reporting}

In light of this theoretical framework, we have proposed a path model ("why-what-how-when") (see table 4) for the selection of an IC approach, useful to satisfy the company's stakeholders informational needs. It will also be applied in the following case study. 
Table 4. The path model for the selection of a useful IC approach

\begin{tabular}{ll}
\hline AGENDA \\
\hline 1. Why implement an IC tool in a specific context? \\
2. What IC approach/tool is suitable to satisfy users informational needs? \\
3. How is the quality of information? \\
4. When is information available? \\
\hline
\end{tabular}

Our paper forms part of the so-called "third stage of research on IC" (Guthrie et al., 2012; Dumay, 2013; Dumay \& Garanina, 2013). According to Guthrie et al. (2012), the third stage is characterized by research critically examining IC in practice, focused on the managerial implications of using IC in managing a company. Guthrie et al. (2012) argue that the third stage of IC research began with the 2004 special issue of JIC entitled "IC at the crossroads-theory and research" (Chatzkel, 2004; Marr \& Chatzkel, 2004). Then, Mouritsen's paper "Problematizing Intellectual Capital research: Ostensive versus Performative IC" (2006) offered an interesting framework for researchers, and further suggestions came from the special issue of Critical Perspectives in Accounting - CPA (Vol. 20, No. 7) called "Critical perspectives on Intellectual Capital" (Mouritsen \& Roslender, 2009; Roslender \& Stevenson, 2009).

Following the IC-performative research stream (Mouritsen, 2006), we advocate that IC is a representation of knowledge resources, the transformative qualities that emerge in application. Thus, measurement is "convention", useful to understand the idiosyncratic qualities of IC and to interpret its role within a specific organizational context. Furthermore, the underlying question of our model is how information about IC will help managers and/or other users of IC reporting to intervene in processes of organizational knowledge development, sharing and application (Mouritsen \& Larsen, 2005, p. 372).

\section{Research Methodology}

The interpretivist model (Crotty, 1998), is the theoretical paradigm accounting for our research. Taking interpretivism into consideration, we see that sociological phenomena cannot be simply perceived but must also be deciphered by the researcher. Therefore, this indicates that there isn't only one absolute reality, but rather different prospects that are brought about by the perspective chosen to expound on the facts (ontological dimension). Since the process of understanding derives from deductive-inductive development (epistemological dimension), separation between researcher and subject cannot occur (Ryan, Scapens, \& Theobald, 2002, p. 34).

So far, empirical data has been gathered in order to obtain information to discuss the power of the proposed framework able to satisfy the informational needs for identifying, measuring and managing its intangible resources. Consistent with the adopted theoretical paradigm and interpretive framework, we decided to adopt a qualitative approach based on the field case study (Yin, 2013).

Following Yin's definition, the field case-study is «an empirical inquiry that investigates a contemporary phenomenon within its real-life context, especially when the boundaries between phenomenon and context are not clearly evident» (Yin, 2003, p. 13).

In the field case study, it is necessary to define:

- The research focus;

- The context/background;

- The number of cases to be considered.

Our inquiry concerns the selection of an Intellectual Capital approach in a high tech company.

In the aerospace and defense sector, to which our selected company has an affiliation, there are large global competitors, whose products and services incorporate a high value of technology. Not only does this technology extend from the financial capital of the firms but also from its human, structural and relational capital spheres.

We chose to focus our attention on the case of a large company leader in systems integrators with headquarters located in Italy. This allowed us to take part in the process of identification, measurement and management of the company's intangible resources. To develop a case study it is necessary to gather different types of information in order to contextualize the investigated phenomenon, thus, we looked for information on the industry sector and the company profile from different sources such as, academic reviews, newspapers and local journals, the firm's web site, financial reporting and available documents. Extremely useful were direct interviews and several focus groups with the company's managers. 


\section{Case study}

\subsection{The Aerospace and Defense Sector}

Players in the aerospace and defense sector are generally large, integrated multinational companies. This scale, making it difficult for new companies to enter the market, is a problem that is even more exacerbated by the high capital expenditure and expertise required for market success to be achieved.

These qualities are crucial for company success because of the highly specialized work. Within the industry, companies are required to adhere to strict regulations including national security, export restrictions and licensing for military goods, accounting rules and safety requirements.

Rivalry in this market is substantial. This is a market dominated by large multinationals that are extremely varied to regard to both the range of products they manufacture and their geographical presence.

Factors such as the rising threat of global terrorism have led to the defense sector being one of the most lucrative business sectors at the beginning of the $21^{\text {st }}$ century, with the market growing steadily. In contrast, civil aerospace has experienced downturns with loss-making airlines unable to countenance high capital expenditures on new planes, making the market less lucrative. Finally, companies use innovation and new technology to differentiate their service (Data Monitor, 2010).

\subsection{The Company Profile}

The company is owned by an Italian listed multinational company, which designs and develops Large Systems for Homeland Protection, as well as systems and radars for air defense, battlefield management, naval defense, air and airport traffic management and coastal and maritime surveillance.

Its headquarters are located in Italy but the company also has a strong international presence in Germany, the US and the United Kingdom. Other plants are in France, Spain and the Netherlands. The company has about 4,200 employees in Italy, Germany, the United Kingdom, USA, France, Spain and the Netherlands. $80 \%$ of them have diplomas and graduate degrees, and 50\% of them are employed in R\&D and engineering activities.

With a fifty-year track record in system integration, the company has a customer base in 150 countries and its 2009 revenues amount to 902.9 million Euros.

A leader in product technological innovation - about $20 \%$ of revenues are invested in R\&D programs - the company is particularly committed to customer support, an area in which it operates jointly with its systems' end users, defining tailored solutions to ensure efficient, timely and continuous assistance.

As a pillar of its management style, the company has based its organizational model on creating value for the shareholder. The model applied involves all company processes and resources and considers value as the fulcrum of operational management. As a consequence of its mission and the awareness that knowledge, employee innovativeness and experience are the principal drivers of company performance, the company decided to invest in several initiatives to increase its Intellectual Capital, among them are:

\section{1) Business growth through knowledge sharing}

Ever since its foundation, the company has been an active member of a knowledge-sharing network, which, in its five years of activity, has promoted technological development and innovation within the group.

There are currently seven communities, each with a specific mission: Radar, Homeland Security, Software \& Capability Maturity Model Integration, Materials, Simulation for Training, Integrated Environment for Design \& Development Community, Logistics \& Services. These "knowledge aggregations" are the true driving force of a shared culture, capable of giving value to innovation.

Another interesting initiative to highlight is the company "Radar and Systems School", whose foundation dates back to over 30 years ago. This initiative, chiefly targeting newly recruited personnel, is based on flexible and two-way teaching processes, meaning that everyone can be a teacher or student from time to time, initiating a virtuous circle that creates a dense network of culture and knowledge exchanges. The courses have recently been opened to customers as well, for the purpose of disseminating the company's skills and supporting industry professionals in choosing the most suitable product for their needs.

\section{2) The "Well-being Project"}

The company promotes industrial process improvement policies to link greater production efficiency to an enhanced well-being of employees. The backdrop is the awareness that workers - their professional experience and cultural and emotional backgrounds alike - are a key factor of the company management model. 
In 2005, the company launched the "Well-being Project", to offer staff innovative solutions and services, capable of harmonizing their work activity with their private lives. One of the main initiatives is the construction of a nursery school at the Rome site. The "Well-being Project" agenda also comprises the organization of placements in Italy and abroad for employees' children, along with in-house events, some typically company-oriented, others with a broader scope.

Finally, as to employees health and safety management, the company endorses top policies. The company also cherishes employee quality enhancement objectives, a factor entailing value creation and strengthening of identity.

\subsection{Case Study Findings}

Our investigation concerns the selection of an Intellectual Capital approach in a high-level technology company. Below, the findings will be presented from the point of view of our suggested path model (why-what-how-when).

Discussion will follow.

\subsubsection{Visualizing the company's Intellectual Capital}

All information that was gathered from the sector and the company profiles has helped us to make sense of why it was essential for the company to focus its attention on intangible resources.

Increasing competition in innovation and new technology has required this company to expand both intangible stock and the effectiveness and efficiency of its use.

Increasing intangible stock means, initially, to map out the crucial intangible resources. Meanwhile, the resources should sustain the company business model.

Thus, complying with Edvinsson's (1997) suggestion, the company elected to map out its intangible resources, customizing the three well-known classifications of Intellectual Capital as in Figure1.

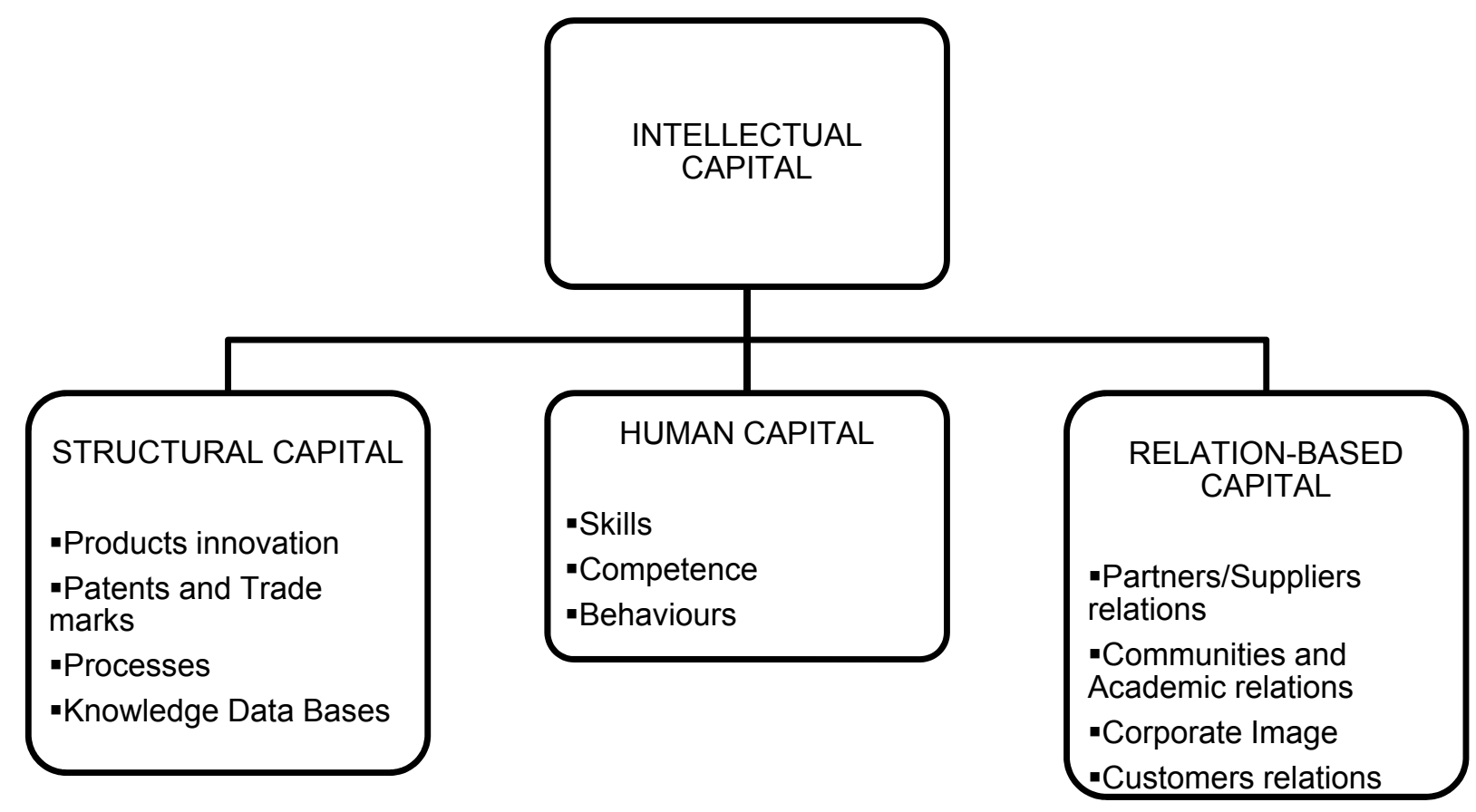

Figure 1. Case study-Visualizing the IC

For the second step, it is necessary to identify which investments should be pushed forward in order:

- Not to lose the existing intangibles within the firm that are not yet codified or captured in the knowledge database (Nonaka and Takeuchi, 1995);

- Increase the intangibles that form the basis of the company's competitive advantage. 
Maximizing the effectiveness and efficacy of intangibles insinuates an added management control perspective. However, information on Intellectual Capital is an input for management activities.

This means that one understands the relationship between different firms' intangible resources and strategies, including the operational activities and organizational contexts.

\subsubsection{The Selection of a Useful IC Tool in a High Tech Company}

However, managers are helpless without an information system customized to fulfill the decision-making process.

In order to define the Intellectual Capital model, related metrics and information system useful for a company's needs, the main users of information and their needs should be identified.

In the analyzed case study, the main IC information users recognized are the company's CEO and the Board of Directors, who need information in order to decide why, what and how much to invest in Intellectual Capital categories such as human, structural and relational capital in order to increase the firm's value.

We realized that the disclosure of Intellectual Capital information to external stakeholders was much more important, however, it would have followed the process which focused on managerial decision-making.

As far as managers were concerned, the company decided to implement the tools shown in Table 5.

Table 5. Case study - Identification of users' informational needs and IC tools

\begin{tabular}{lll}
\hline WHY & WHAT \\
\hline Defined Users & Defined Informational need & Suggested tools (author) \\
CEO, & Managerial decision-making & "Knowledge Narrative" \\
Board of Directors & & (Mouritsen 1998, Mouritsen and Larsen \\
& & 2005) \\
CEO, & Ranking partners and competitors & IC index (Roos et al.1997) \\
Board of Directors & & \\
\hline
\end{tabular}

The reason why the "Knowledge Narrative" method (Mouritsen 1998, Mouritsen and Larsen 2005) was selected to satisfy the firm's Top management informational needs, derives from the fact that this tool is consistent with a competency-based strategy, which generates value focusing first on the skills and know-how of employees and the firm's embedded knowledge.

It first requires to identify the company's mission and the value the company is aiming to create for its clients through the combination of the above-mentioned resources. Then it follows the map of the managerial challenges and related actions to foster the company's key-intangibles, whose level will be periodically monitored by selected indicators.

As an example, focusing only on the following managerial challenge: "Increase collaborations with research centers and Universities", specific initiatives and indicators to monitor the upgrade of key intangibles are shown in table 6.

Table 6. The company IC statement in light of the "knowledge narrative" approach

\begin{tabular}{|c|c|c|}
\hline Challenges (Key intangibles) & Initiatives & Indicators \\
\hline $\begin{array}{l}\text { To increase collaborations and to foster } \\
\text { innovation and knowledge sharing } \\
\text { (Relation-based Capital: Communities and } \\
\text { Academic relations) }\end{array}$ & $\begin{array}{l}\text { - to map out existing collaboration } \\
\text { - to plan new collaborations } \\
\text { to increase no. and employees' } \\
\text { participation to communities of } \\
\text { practice }\end{array}$ & $\begin{array}{l}\text { - } \\
\text { existing collaborations } \\
\text { - } \quad \text { No. of Universities and research } \\
\text { centers involved in networks } \\
\text { - No. of international research } \\
\text { projects in which the company is } \\
\text { involved } \\
\text { No. of communities of practice }\end{array}$ \\
\hline
\end{tabular}


The selection of the IC index (Roos et al. 1997) to draw an intangibles value-based ranking stems from the idea to compare the firm with its partners and competitors on a subset of indicators already gathered, while drawing the company's Intellectual Capital Statement, since it is the result of the "knowledge narrative" approach.

However, it is important to highlight that in order to draft and then implement a chosen Intellectual Capital approach, one should consider, as suggested above, the following primary factors:

- Quality of information available;

- Cost/benefits of information to be gathered.

Thus, in table 7, we will highlight the main problems encountered in gathering and handling data and the solutions suggested to overcome them, which will be discussed in the following paragraph.

Table 7. Case Study - Data quality influences HOW and WHEN an IC tool can be implemented

\begin{tabular}{|c|c|c|c|}
\hline Approach/tool & Informational need & $\begin{array}{l}\text { Problems encountered in data } \\
\text { gathering }\end{array}$ & Suggested Solutions \\
\hline "Knowledge Narrative" & Managerial decision & $\begin{array}{l}\text { Difficulty in gathering } \\
\text { information, which is spread } \\
\text { throughout the company }\end{array}$ & $\begin{array}{l}\text { Identifying information owners and developing } \\
\text { procedures to gather data within the firm. } \\
\text { Analysis of costs-benefits of new information } \\
\text { to be collected. }\end{array}$ \\
\hline IC index & $\begin{array}{l}\text { Ranking partners and } \\
\text { competitors }\end{array}$ & $\begin{array}{l}\text { Scarce availability of published } \\
\text { information for competitors }\end{array}$ & $\begin{array}{l}\text { Evaluation of alternative approaches, focusing } \\
\text { on info gathered from financial reporting (i.e.: } \\
\text { VAIC, Pulic 1997) }\end{array}$ \\
\hline
\end{tabular}

\section{Case study Discussion and Concluding Remarks}

We worked with a joint research group that allowed us to investigate the method for selecting a useful IC approach/tool in the analyzed company from the beginning.

This gave us the opportunity to improve the suggested path model "why-what-how-when" thanks to practical experience (see table 7).

Thus, the main critical factors of the process investigated are the following:

- Accurate identification of actors involved in the decision-making process;

- Quality and availability of information .

Different actors can affect the final selection. They are classified considering the following perspectives:

1) The authority one has in the selection of a suitable IC approach (decision maker(s): i.e. managers of the holding company/CEO/CFO/Board of Directors/etc.; members of the IC research group: i.e. company's managers/consultants/academics);

2) Whether they are users or providers of IC information.

The starting point for the research agenda is the identification of the decision maker's objectives. Given that the decision maker(s) could have several different objectives, this makes the identification of the approach used a critical factor, because the objectives can only be achieved though the use of different IC approaches/tools.

Therefore, the research group's first duty is to help the decision maker(s) choose his objectives, then to map out the information users and their needs.

Furthermore, the distinction of IC information users and providers is of great importance. The first distinction is fundamental in order to analyze their information needs, and the latter is even more crucial because it is concerned with data gathering.

Thus, the research group should recognize information owners and procedures to gather statistics spread throughout the firm.

From an organizational point of view, this requires a lot of dedication from the company's top management (the $\mathrm{CEO}$ in our case study) so that the information owners will provide information.

A further critical point is the assessment of available information quality. This is very crucial, especially for 
information to be collected outside the company.

As far as our case study is concerned, scarce availability and reliability of IC information on competitors encouraged the research group to propose an alternative IC measurement based on financial reporting certified data, different from what was previously envisaged.

Finally, the selection of a suitable IC approach is the output of a complex process which also requires a previous cost-benefit analysis of information that isn't already available.

Table 7. Improving the suggested path model

REVISED AGENDA

Why?

How?/When?

What?
- Identification of primary and secondary actors involved in the process

- Mapping of users informational needs

- First identification of suitable approach(s) to satisfy (multiple) users' needs

- Mapping data already available and assessing information quality

- Costs-benefits analysis to gather information not on hand

Final identification of a useful IC approach/tool to be implemented in the firm

\subsection{Main Results and Implications}

The literature suggests several approaches for the identification, measurement and management of intangibles.

The purpose of this paper is to present the results of an empirical study and the critical factors of a process aiming to identify a useful Intellectual Capital approach to be implemented in a company.

The analyzed case study shows that there isn't "one best way" to report on intangibles. One should consider the different informational needs of a company's stakeholders.

The most significant suggestion we can make for managers and/or professionals tasked with the development and implementation an Intellectual Capital model in a firm, is that not only must the users informational needs be considered but also the information quality and its costs-benefit trade-offs.

Sometimes, in fact, the scarcity and or the low-quality of information gathered may indicate that a company needs to select an alternative IC approaches to reach their objectives.

\subsection{Future Research}

Finally, the study of one case isn't sufficient to generalize our findings. Therefore, maintaining the same theoretical framework, ongoing research will follow up in these two areas:

- The use of the same research question in other case studies;

- The evolution of the examined case study, focusing attention on the company management control of knowledge resources through the information gathered on Intellectual Capital.

\section{References}

Abeysekera, I. (2006). The project of intellectual capital disclosure: researching the research. Journal of Intellectual Capital, 7(1), 61-75. https://doi.org/10.1108/14691930610639778

Andriessen, D. (2004). Making sense of intellectual capital. Designing a method for the valuation of intangibles. Elsevier Butterworth Heinemann, London.

Becerra-Fernandez, R. S. (2001). Organizational knowledge management: A contingency perspective. Journal of Management Information Systems, 18(1), 23-55.

Bismuth, A., \& Tojo, Y. (2008). Creating value from intellectual assets. Journal of Intellectual Capital, 9(2), 228-245. http://dx.doi.org/10.1108/14691930810870319 
Bontis, N. (1998). Intellectual capital: an exploratory study that develops measures and models. Management Decision, 36(2). http://dx.doi.org/10.1108/00251749810204142

Bozzolan, S., Favotto, F., \& Ricceri F. (2003). Italian annual intellectual capital disclosure: An empirical analysis Journal of Intellectual Capital, 4(4), 423-436. http://dx.doi.org/10.1108/14691930310504554

Chatzkel, J. (2004). Moving through the crossroads. Journal of Intellectual Capital, 5(2), 337-339. http://dx.doi.org/10.1108/14691930410533740

Chen, M. C., Cheng, S. J., \& Hwang, Y. (2005). An empirical investigation of the relationship between intellectual capital and firms' market value and financial performance. Journal of Intellectual Capital, 6(2), 159-176. http://dx.doi.org/10.1108/14691930510592771

Chiucchi, M. S. (2013a). Intellectual capital accounting in action: enhancing learning through interventionist research. Journal of Intellectual Capital, 14(1), 48-68. http://dx.doi.org/10.1108/14691931311289011

Chiucchi, M. S. (2013b). Measuring and reporting intellectual capital: Lessons learnt from some interventionist research projects. Journal of Intellectual Capital, 14(3), 395-413. http://dx.doi.org/10.1108/JIC-03-2013-0036

Crotty, M. (1998). The foundations of Social Research. Sage Publication, London.

Danish Ministry of Science, Technology and Innovation. (2003). Intellectual Capital Statements-The new guideline.

Demartini, P., \& Paoloni, P. (2013a). Implementing an intellectual capital framework in practice. Journal of Intellectual Capital, 14(1), 69-83. http://dx.doi.org/10.1108/14691931311289020

Demartini, P., and Paoloni, P. (2013b). Awareness of your own intangible assets: A hypothesis of overlapping between ICS and CSRS processes. Journal of Intellectual Capital, 14(3), 360-375. http://dx.doi.org/10.1108/JIC-03-2013-0039

Dumay, J. (2013). The third stage of IC: Towards a new IC future and beyond. Journal of Intellectual Capital, 14(1), 5-9. http://dx.doi.org/10.1108/14691931311288986

Dumay, J. (2014). 15 years of the journal of intellectual capital and counting: a manifesto for transformational IC research. Journal of Intellectual Capital, 15(1), 2-37. http://dx.doi.org/10.1108/JIC-09-2013-0098

Dumay, J. (2016). A critical reflection on the future of intellectual capital: From reporting to disclosure. Journal of Intellectual Capital, 17(1), 168-184. http://dx.doi.org/10.1108/JIC-08-2015-0072

Dumay, J. C. (2012). Grand theories as barriers to using IC concepts. Journal of Intellectual Capital, 13(1), 4-15. http://dx.doi.org/10.1108/14691931211196187

Dumay, J. C., \& Tull, J. A. (2007). Intellectual capital disclosure and price-sensitive Australian Stock Exchange $\begin{array}{lllll}\text { announcements. Journal of } & \text { Intellectual }\end{array}$ http://dx.doi.org/10.1108/14691930710742826

Dumay, J., \& Garanina, T. (2013). Intellectual capital research: a critical examination of the third stage. Journal of Intellectual Capital, 14(1), 10-25. http://dx.doi.org/10.1108/14691931311288995

Dumay, J., Bernardi, C., Guthrie, J., \& Demartini, P. (2016, in press). Integrated reporting: A structured literature review. Accounting Forum. http://doi.org/10.1016/j.accfor.2016.06.001

Edvinsson, L. (1997). Developing intellectual capital at Skandia. Long Range Planning, 30(3), 266-373.

Edvinsson, L. (2013). IC 21: reflections from 21 years of IC practice and theory. Journal of Intellectual Capital, 14(1), 163-172. http://dx.doi.org/10.1108/14691931311289075

Edvinsson, L., \& Malone, M. S. (1997). Intellectual Capital. Piatkus, London.

Edvinsson, L., \& Stenfelt, C. (1999). Intellectual capital of nations-for future wealth creation. Journal of Human Resource Costing \& Accounting, 4(1), 21-33. http://dx.doi.org/10.1108/eb029051

Fasb. (2001). Improving business reporting: insights into enhancing voluntary disclosures. Retrieved from http://www.fasb.org

Freeman R. E. (1994). The politics of stakeholder theory. Business Ethics Quarterly, 4(4), 409-421. https://doi.org/10.2307/3857340

Freeman, R. E. (2010). Strategic management: A stakeholder approach. Cambridge University Press. 
Freeman, R. E., Harrison, J. S., Wicks, A. C., Parmar, B. L., \& De Colle, S. (2010). Stakeholder theory: The state of the art. Cambridge University Press.

Giuliani, M. (2013). Not all sunshine and roses: discovering intellectual liabilities "in action". Journal of Intellectual Capital, 14(1), 127-144. http://dx.doi.org/10.1108/14691931311289057

Graham, J. R., Harvey, C. R., \& Rajgopal, S. (2005). The economic implications of corporate financial reporting. Journal of accounting and economics, 40(1), 3-73. http://doi.org/10.1016/j.jacceco.2005.01.002

Grant, R. M. (1998). Contemporary Strategy Analysis. Blackwell Business, Malden, MA

Guthrie, J., Petty, R., \& Ricceri, F. (2006). The voluntary reporting of intellectual capital: Comparing evidence from Hong Kong and Australia. Journal of Intellectual Capital, 7(2), 254-271. http://dx.doi.org/10.1108/14691930610661890

Guthrie, J., Petty, R., Yongvanich, K., \& Ricceri, F. (2004). Using Content Analysis as a Research Method to Inquire into Intellectual Capital Reporting. Journal of Intellectual Capital, 5(2), 282-293. http://dx.doi.org/10.1108/14691930410533704

Guthrie, J., Ricceri, F., \& Dumay, J. (2012). Reflections and projections: a decade of intellectual capital accounting research. The British Accounting Review, 44(2), 68-82. http://doi.org/10.1016/j.bar.2012.03.004

Hamel, G., \& Prahalad, C. K. (1994). Competing for the future. Boston, MA.: Harvard Business School Press.

International Integrated Reporting Council (IIRC). (2013). The International $<I R>$ Framework. International Integrated Reporting Council, London.

Kaplan, R. S., \& Norton, D. P. (1996). The Balanced Scorecard - Translating strategy into action. Boston, MA: Harvard Business School Press.

Kujansivu, P. (2009). Is there something wrong with intellectual capital management models?. Knowledge Management Research and Practice, 7(4), 300-307. https://dx.doi.org/10.1057/kmrp.2009.23

Lev, B. (2001). Intangibles: Management and Reporting. Washington D.C.: Brookings Instituion Press,

Lev, B., \& Zambon, S. (2003). Intangibles and Intellectual Capital: an introduction to a special issue. European Accounting Review, 12(4), 597-603. http://dx.doi.org/10.1080/0963818032000162849

Lev, B., \& Zarowin, P. (1999). The boundaries of financial reporting and how to extend them, Journal of Accounting Research, 37, 353-385. https://dx.doi.org/10.2307/2491413

Lönnqvist, A., Kianto, A., \& Sillanpää, V. (2009). Using intellectual capital management for facilitating organizational change. Journal of Intellectual Capital, 10(4), 559-572. http://dx.doi.org/10.1108/14691930910996643

Lönnqvist, A., Sillanpää, V., \& Carlucci, D. (2009). Intellectual capital management in practice: Assessment of implementation and outcomes. Knowledge Management Research \& Practice, 7(4), 308-316. https://dx.doi.org/10.1057/kmrp.2009.22

Maditinos, D., Chatzoudes, D., Tsairidis, C., \& Theriou, G. (2011), The impact of intellectual capital on firms' market value and financial performance, Journal of Intellectual Capital, 12(1), 132-151. http://dx.doi.org/10.1108/14691931111097944

Marr, B., \& Chatzkel, J. (2004). Intellectual capital at the crossroads: managing, measuring, and reporting of IC. Journal of Intellectual Capital, 5(2), 224-229. http://dx.doi.org/10.1108/14691930410533650

Marzo, G. (2014). Improving internal consistency in IC research and practice: IC and the theory of the firm. Journal of Intellectual Capital, 15(1), 38-64. http://dx.doi.org/10.1108/JIC-03-2013-0026

Mouritsen, J. (1998). Driving growth: economic value added versus intellectual capital. Management Accounting Research, 9(4), 461-483. https://doi.org/10.1006/mare.1998.0090

Mouritsen, J. (2006). Problematising intellectual capital research: ostensive versus performative IC. Accounting, Auditing \& Accountability Journal, 19(6), 820-841. http://dx.doi.org/10.1108/09513570610709881

Mouritsen, J., \& Larsen, H. T. (2005). The $2^{\text {nd }}$ wave of knowledge management: The management control of knowledge resources through intellectual capital information. Management Accounting Research, 16, 371-94. http://doi.org/10.1016/j.mar.2005.06.006

Mouritsen, J., \& Roslender, R. (2009). Critical intellectual capital. Critical Perspectives on Accounting, 20(7), 801-803. 
Mouritsen, J., Larsen, H. T., \& Bukh, P. N. (2001). Intellectual capital and the "capable firm": Narrating, visualising and numbering for managing knowledge. Accounting, Organizations \& Society, 26(7/8), 735-762. http://doi.org/10.1016/S0361-3682(01)00022-8

Mouritsen, J., Larsen, H. T., \& Bukh, P. N. (2005). Dealing with the knowledge economy: Intellectual capital versus balanced scorecard. Journal of Intellectual Capital, 6(1), 8-27. http://dx.doi.org/10.1108/14691930510574636

Nielsen, C., Roslender, R., \& Schaper, S. (2016). Continuities in the use of the intellectual capital statement approach: Elements of an institutional theory analysis. In Accounting Forum, 40(1), 16-28. http://doi.org/10.1016/j.accfor.2015.11.002

Nonaka, I., \& Takeuchi, H. (1995). The Knowledge-creating company. Oxford University Press, Oxford.

Organisation for Economic Co-operation and Development (OECD). (1999). Guidelines and instructions for OECD Symposium. International Symposium Measuring Reporting Intellectual Capital: Experiences, Issues, and Prospects, June, Amsterdam, OECD, Paris.

Petty, R., \& Guthrie, J. (2000). Intellectual capital literature review: measurement, reporting and management. Journal of Intellectual Capital, 1(2/3), 155-76, http://dx.doi.org/10.1108/14691930010348731

Petty, R., \& Guthrie, J. (2000). Intellectual capital literature review: measurement, reporting and management. Journal of intellectual capital, 1(2), 155-176, http://dx.doi.org/10.1108/14691930010348731

Petty, R., Ricceri, F., \& Guthrie, J. (2008). Intellectual capital: A user's perspective. Management Research News, 31(6), 434-447. http://dx.doi.org/10.1108/01409170810876035

Pew Tan, H., Plowman, D., \& Hancock, P. (2008). The evolving research on intellectual capital. Journal of intellectual capital, 9(4), 585-608, http://dx.doi.org/10.1108/14691930810913177

Pike, S., \& Roos, G. (2007). 10 The validity of measurement frameworks: measurement theory. Business Performance Measurement, 218.

Porter, M. E. (1985). Competitive Advantage: creating and sustaining superior performance. New York: Free Press.

Riahi-Belkaoui, A. (2003). Intellectual capital and firm performance of US multinational firms: A study of the resource-based and stakeholder views. Journal of Intellectual Capital, 4(2), 215-226. http://dx.doi.org/10.1108/14691930310472839

Roos, J., Roos, G., Dragonetti, N. C., \& Edvinsson, L. (1997). Intellectual Capital: Navigating in the New Business Landscape. Macmillan Business, Houndsmills.

Roslender, R., \& Stevenson, J. (2009). Accounting for people: A real step forward or more a case of wishing and hoping? Critical Perspectives on Accounting, 20(7), 855-869. http://doi.org/10.1016/j.cpa.2007.02.003

Ryan, B., Scapens, R., \& Theobald, M. (2002). Research Method and Methodology in Finance and Accounting, Thomson, London.

Stewart, T. A. (1997). Intellectual capital. Nicholas Brealey Publishing, London.

Sveiby, K. E. (1997). The new organizational wealth: managing and measuring knowledge-based asset. Berrett-Koehler, San Francisco, CA.

Sveiby, K. E., Gripenberg, P., \& Segercrantz, B. (Eds) (2012). Challenging the Innovation Paradigm, Routledge Studies in Technology, Work and Organizations, Routledge, New York, NY and London.

United Nations Global Compact (UNGC). (2009). Overview of the UN Global Compact. Retrieved from http://www.unglobalcompact.org/AbouttheGC/index.html

Wee, J. C., \& Chua, A. Y. (2016). The communication of intellectual capital: the "whys" and "whats". Journal of Intellectual Capital, 17(3). http://dx.doi.org/10.1108/JIC-01-2016-0007

Yin, R. K. (2003). Case study research: design and methods (3rd ed.). Sage.

Yin, R. K. (2013). Case study research: Design and methods. Sage public. 


\section{Copyrights}

Copyright for this article is retained by the author(s), with first publication rights granted to the journal.

This is an open-access article distributed under the terms and conditions of the Creative Commons Attribution license (http://creativecommons.org/licenses/by/4.0/). 